\title{
Teaching Research and Practice of University Mathematics Courses Adapted to Applied Talent Training Model
}

\author{
$X U \mathrm{Hui}^{1,}$,,$X U \mathrm{Na}^{2, \mathrm{~b}}$ \\ ${ }^{1}$ College of Mathematics and Statistics, Baicheng Normal University, Baicheng,137000,China \\ ${ }^{2}$ Mingren Elementary School,Taobei District, Baicheng,137000, China \\ aemail: 358999206@qq.com, bemail:168677791@qq.com
}

Keywords: Applied talent; Training model; University mathematics; Courses teaching

\begin{abstract}
The acceleration of the development of higher education in China under the current situation has had a positive impact on the development of mathematics teaching in universities. In practice, in order to ensure the effectiveness of university mathematics curriculum and maintain its good teaching effect, it is necessary to pay more attention to the application of the applied talents training model, and to enhance the potential application value of the corresponding university mathematics courses. Based on this, this paper discusses the teaching of university mathematics courses which is suitable for the training mode of applied talents.
\end{abstract}

\section{Introduction}

Paying attention to the teaching research and practical analysis of university mathematics courses, which adapts to the mode of cultivating applied talents, is helpful to strengthen the practical application effect of this kind of courses, and to promote the students' mathematics ability to improve gradually, so as to inject vitality into the development of university education in China. Therefore, it is necessary to combine the actual situation and the current situation change, start from different aspects, and actively carry out the teaching and research work of university mathematics course, which adapts to the mode of cultivation of applied talents, so that the practical teaching level of this kind of courses can be continuously improved in the long-term practice, so as to maintain a good teaching situation of university mathematics and ensure the reliability of teaching quality.

\section{Analysis on the Measures of Improving the Teaching Level of Mathematics Courses in Universities in Accordance with the Training Model of Applied Talents}

In order to improve the teaching level of mathematics courses which adapt to the training mode of applied talents, it is necessary to take full consideration from different angles, find out the corresponding measures and use them to make sure that the practice teaching of this course is in good condition. These measures specifically include the following:

Attach Importance to the Flexible Use of Mathematical Ideas and Methods. The implementation of the teaching work of college mathematics courses based on the training model of applied talents needs to be combined with the actual conditions of different mathematics classes such as higher mathematics and linear algebra. Through the scientific training of the students ability of using mathematical methods and the ability of data processing, the mathematical quality of the applied talents is improved in the long-term practice process. Therefore, it is necessary to attach importance to the flexible use of mathematical thinking and methods in order to improve the teaching level of mathematics courses that is suitable for the training mode of applied talents. In the meantime, this needs to be done:(1)on the basis of considering the teaching requirements of higher mathematics and linear algebra in the course of university mathematics, through the rational application of different mathematical thought methods, such as analysis and induction, calculus, approximation and iteration, make the teaching work of university mathematics courses more targeted, so as to meet the needs of the cultivation of applied talents;(2)in the course of mathematics 
teaching, teachers should consider the effective use of the model of cultivating applied talents, and then explain the abstract mathematics knowledge directly and vividly with the support of multimedia teaching means, that enables students to deepen their understanding of what they have learned, and to have a comprehensive understanding of different basic mathematical thinking methods in mathematics learning, such as variable substitution, countervailing, and so on. On this basis, it is beneficial to stimulate students potential in mathematics, improve their creative thinking ability, enhance the application effect of mathematical thinking methods, and realize the efficient utilization of applied talents training mode at the same time[1]. For example, in the teaching process of higher mathematics, teachers can pay attention to the reasonable use of variable substitution method in their teaching process, so as to improve the efficiency of solving problems in the aspects of differential equation solving and Fourier series calculation, so as to realize applied talents training who is needed in the practice of university mathematics courses.

Strengthen Students' Consciousness of Applied Mathematics and Strengthen their Ability to Apply Mathematics. In the practical teaching of university mathematics courses, teachers analyze the mastery degree of basic knowledge of students and guide them to use the knowledge that they have learned to deal with practical problems, thus arousing students more interest in learning to meet the training requirements of applied talents in mathematics teaching[2]. Therefore, it is necessary to strengthen students' applied mathematics knowledge and strengthen their ability to apply mathematics in the process of improving the teaching level of university mathematics courses which is suitable for the training mode of applied talents. The specific performance is as follows: (1) In the implementation of the college mathematics curriculum teaching plan, the teachers can guide the students to connect closely with their own life practice and strengthen their application mathematics consciousness, so as to stimulate the students' enthusiasm for learning and improve their active learning, so that the students can draw more mathematical knowledge in the process of the practice; (2) By fully considering the applied contents in the teaching materials of mathematics, teachers can carry out the teaching work pertinently, so that the students' ability of applying mathematics can be trained scientifically. For example, when carrying out the teaching work of linear algebra, teachers can carry out the corresponding teaching work through the flexible use of the application of matrix, the solution of linear equations, and so on, that makes students improve their mathematics application ability in the process of learning these contents, thus lay a solid foundation for their all-round development.

Improve the Efficiency of Information Technology Utilization and Optimize Teaching Methods. In the course of college course teaching, in order to build efficient mathematics teaching class and maintain a good atmosphere of classroom teaching, teachers need to analyze the requirements of teaching syllabus and the specific situation of students in the teaching of higher mathematics, linear algebra, probability theory and mathematical statistics, so as to improve the efficiency of the use of information technology in an all-round way, that is more scientific to use the teaching methods needed in mathematics courses[3]. The specific performance is as follows:(1)In the teaching of mathematics courses, teachers should strengthen their own information consciousness, and attach importance to the scientific cultivation of personal information technology ability in the long practice to make the mathematics teaching under the action of information technology more efficient, and gradually improve the students mathematics application ability, maintain their good mathematical thinking imagination; (2)In the course of college mathematics teaching, teachers should integrate information technology into their own teaching work, and enrich the content of classroom teaching under the coordination of computer network, realize the optimization of the existing teaching methods, increase the technical content in the teaching of mathematics courses in the university, so as to effectively cultivate the students' application ability in mathematics. Support is provided. For example, in the course of explaining the Lagrange mean value theorem and the zero point theorem of continuous function in closed interval, teachers can make use of the advantages of information technology and computer network to actively carry out the corresponding mathematics teaching work. It makes the efficiency of mathematics classroom teaching improve gradually, and meets the requirement of cultivating 
students' mathematics application ability while optimizing the teaching method[4].

Pay Attention to the Integration and Application of Mathematics Knowledge and Methods between Different Courses. In the process of improving the teaching level of mathematics courses suitable to the applied talents training model, if the relevant educators can attach importance to the integration and application of mathematical knowledge and methods among different courses, that is helpful to maintain the good teaching condition of mathematics courses in universities. The specific performance is as follows:(1)Many numerical approximate calculation methods are introduced in higher mathematics, such as differential or total differential used in approximate calculation, approximate solution of equation, approximate calculation of definite integral, approximate calculation of numerical value by power series expansion, etc. When these methods are combined with programming language, approximate numerical calculation can be made. The knowledge of unitary and multivariate calculus, functions and series in higher mathematics is widely used in probability and statistics, which enhances the potential application value of the knowledge points contained in these different disciplines;(2)Determinant in linear algebra is used to express vector product and mixed product of vector; matrix knowledge is introduced into covariance study of probability and statistics; linear correlation or independent elicitation function is similar to vector and so on. If we grasp these fusion points in teaching, it will help to train the students' ability to analyze and solve problems by comprehensive application of knowledge. Therefore, in the teaching of university mathematics courses, teachers should carry out the corresponding mathematics teaching according to the knowledge system structure of different courses, so that the quality of classroom teaching can be guaranteed reliably[5]. For example, the integration of functional knowledge in higher mathematics can broaden the teaching ideas of teachers in probability and statistics teaching and then that plays its due role in the cultivation of students mathematics application ability and enriches the classroom teaching content.

Guide Students to Pay Attention to the Cooperation of Calculators and Mathematical Software and Improve their Mathematical Ability. In the process of applying mathematics to solve practical problems, graphics drawing, numerical calculation and data processing are inevitable, so it is necessary to have computer knowledge and the ability to use mathematical software. For those schools which have not set up mathematics experiment courses, they can squeeze out 2-5 hours in the hours of higher mathematics and probability statistics, and simply introduce Excel SAS software, etc., and arrange some topics for students to practice after class to train students to use calculators and mathematical software to solve practical problems of numerical calculation and data processing ability. For example, in the teaching of advanced mathematics, linear algebra and other courses, teachers can learn to use SAS software to deal with practical mathematical application problems through scientific guidance to students in mathematics learning, that can effectively cultivate students' ability to apply mathematics and improve students' ability of mathematics[6].

Strengthen the Cultivation of Mathematical Quality in Addition to the Routine Teaching of Mathematics Courses for Students. In addition to the contents mentioned above, it is necessary to strengthen the cultivation of mathematics quality of students in the process of improving the teaching level of mathematics courses in accordance with the mode of cultivating applied talents. The specific performance is as follows:(1)Teachers should encourage students to use mathematical methods to carry out quantitative research in extracurricular scientific research projects, graduation thesis writing and service society so as to ensure the feasibility and accuracy of data processing and the validity of experimental results to improve the students' mathematics quality;(2)Through the analysis of students' overall performance in mathematics course teaching, teachers should guide or organize students to refer to various mathematics competition activities, so that their mathematical quality can be better cultivated[7]. For example, in the teaching and research of university mathematics courses, it can broaden students' thinking and imagination space and their learning horizon so as to maintain their own good mathematical quality that organizing students to participate in nationwide mathematical modeling competitions. 


\section{An Analysis of the Teaching Practice of Mathematics Courses in Colleges and Universities Adapted to the Training Mode of Applied Talents}

In order to make full use of mathematics courses in colleges and universities adapted to the applied talents training model, it is necessary to strengthen its teaching practice analysis. This is manifested in the following areas:

In the teaching of undergraduate mathematics courses, through the analysis of the actual teaching situation of science and technology undergraduate, management undergraduate and social science undergraduate course, the corresponding teaching work of mathematics classes is put into practice, and through the analysis of the structure of linear algebra, higher mathematics and probability statistics knowledge system, the scientific cultivation of students' mathematical quality is realize, that enables them to maintain enough mathematical enthusiasm in good mathematics teaching mode. During this period, because the teaching work of university mathematics course plays an important role in the cultivation of applied talents, it realizes the scientific cultivation of students' mathematical application ability and strengthens their awareness of the practical application of mathematics[8]. In order to improve the overall teaching level of mathematics courses in colleges and universities, it is necessary to consider the requirements of the cultivation of applied talents in the teaching of mathematics courses in the undergraduate stage, and carry out the teaching work in order to improve the overall teaching level of mathematics courses in universities.

In the teaching of mathematics courses in higher vocational colleges, in order to make students master professional skills, it is necessary for teachers to pay attention to the cooperation of theory teaching and practice teaching, and directly select the mathematics knowledge needed in the course of mathematics teaching and carry on the key explanation on the base of being able to make clear the requirements of cultivating applied talents in the teaching of mathematics courses, so that the students can deepen the understanding of mathematical knowledge such as Laplace transformation and the Fourier series.

\section{Conclusion}

To sum up, under the function of the applied talents training mode, it which has important practical reference significance that the teaching and research work of the university mathematics course is put into practice: it is beneficial to optimize the teaching methods in the practice of this kind of courses, so that the expected results can be achieved in the application of university mathematics courses, and accumulated rich practical experience for the development of university mathematics courses. Therefore, in the future, more attention should be paid to the mode of cultivating applied talents in the teaching practice of university mathematics courses in our country, so as to ensure that the overall teaching level of university mathematics courses, which is suitable for this model, can be maintained at a higher level.

\section{References}

[1]YIN Wenshuang, XIAO Changcheng. Teaching Exploration of University Mathematics Course in the Course of Specialty Transformation and Development[J]. Science \& Technology Vision,2016(07):83-84.

[2]SUN Linan, LUO Linan. Research and Practice on Teaching Reform of Mathematics Series courses in Universities under the Mode of Cultivating Applied Talents[J].Journal of Heihe University,2015(06):72-74.

[3]HUO Haifeng,WEI Lanyong. Discussion and Practice on Teaching Reform of Mathematics in the Transformation period of Independent College[J].University Education,2015(07):102-103.

[4]LI Hao. Discussion on the Combination of Mathematical Modeling Thought and Mathematics Course Teaching in University[J].The Guide of Science \& Education,2014(12):166-167. 
[5]CAO Xihong. Research on Undergraduate Course Setup of Mathematics Education Specialty from the Perspective of Teacher Education Excellence[D]. Hunan Normal University, 2013(05):10-22.

[6]LI Shitao, TENG Yong. Teaching Reform of Mathematics Course Based on Excellence Engineer Plan[J].Journal of Changchun Institute of Technology(Social Sciences Edition),2013(01):120-122.

[7]YNAG Huiqing, LI Qinghong. Analysis on Teaching orientation of Mathematics Course in Applied Undergraduate University[J].Journal of Suzhou University,2011(11):91-93.

[8]LI Shiwei. Teaching Reform and Practice of College Mathematics Class Based on Professional Demand[J].New West,2011(10):171-172. 